This item was submitted to Loughborough's Research Repository by the author.

Items in Figshare are protected by copyright, with all rights reserved, unless otherwise indicated.

\title{
'A girl's love': Lord Alfred Douglas as homoerotic muse in the poetry of Olive Custance
}

PLEASE CITE THE PUBLISHED VERSION

http://dx.doi.org/10.1080/09574042.2011.585045

PUBLISHER

(C) Taylor \& Francis

VERSION

AM (Accepted Manuscript)

\section{PUBLISHER STATEMENT}

This work is made available according to the conditions of the Creative Commons Attribution-NonCommercialNoDerivatives 4.0 International (CC BY-NC-ND 4.0) licence. Full details of this licence are available at: https://creativecommons.org/licenses/by-nc-nd/4.0/

\section{LICENCE}

CC BY-NC-ND 4.0

\section{REPOSITORY RECORD}

Parker, Sarah L.. 2019. “'A Girl's Love': Lord Alfred Douglas as Homoerotic Muse in the Poetry of Olive Custance”. figshare. https://hdl.handle.net/2134/22672. 


\section{'A Girl's Love': \\ Lord Alfred Douglas as Homoerotic Muse in the Poetry of Olive Custance}

In contrast to some of her Yellow Book and Bodley Head contemporaries, Olive Custance (1874 - 1944) has yet to be the subject of a sustained critical revival. Even amongst scholars of fin de siècle poetry, she remains primarily best known as the wife of Lord Alfred Douglas, who is himself chiefly remembered as the lover of Oscar Wilde. Another arena in which Custance's name arises is that of lesbian biography, in which her rumoured entanglements with Natalie Barney and Renée Vivien in Paris attract passing interest (Wickes 1977: 58-60; Souhami 2004: 56-51). But although the details of Custance's personal life are admittedly intriguing, her poetry itself has received little critical comment. In part, this is due to Custance's difficult historical positioning. Publishing her first volume in 1897, and three subsequent volumes between 1902-1911, the majority of Custance's output falls outside the bounds the fin de siècle, which some critics argue ends in 1895, following Wilde’s imprisonment (Robbins 1995: 137). However, whilst not fitting easily into definitions of the late-Victorian, Custance's decadent poetry is also out of place in the early twentieth century. Holbrook Jackson groups her with the 'minor poets' who 'give expression to moods more attuned to end-of-the-century emotions' (Jackson 2002: 163). By 1906, Custance's writing-style was considered out-of-date: The Saturday Review criticised her third volume The Blue Bird (1905) in the following terms: 'Here the spirit and manner of a school of verse which flourished in Oxford early in the last decade [...] are reproduced with monotonous fidelity' ('Little Verse', June 2 1906: 694). 
Custance's problematic position as a distinctly fin de siècle poet who published nothing following the Great War, contributes to an image of her as irrelevant to the concerns of modernity. However, when Jackson describes the 'minor note’ in Custance’s work as ‘a form of hermaphroditism’ (Jackson 2002: 166-7) — he provides a clue to how her work can be reconsidered in terms highly relevant to both fin de siècle and modernist studies. In this article, I attempt to show that in Custance's brief but intense poetic career, she achieves this 'hermaphroditism' by manipulating the discourses of aestheticism, decadence and nascent Sapphic modernism. In arguing for Custance's productive engagement with fin de siècle discourses of sexual dissidence, I suggest that the complex eroticism of Custance's work is not just a fleeting 'phase' characteristic of fin de siècle literature, but actually marks the beginning of a much larger project of destabilising gender and sexuality. This destabilisation takes place at the very moment in which sexual 'inversion' is being defined, and anticipates the later work of modernist poets such as H.D. Thus, what marks Custance as a representative product of the fin de siècle — that 'minor, hermaphroditic' note - is also what makes her relevant to the twentieth (and twentyfirst) centuries; her constructions of gender and sexuality anticipate what is now termed queer. Like the colour-shifting opal stone that she made her symbol, Custance refused to be defined by any one discourse of sexuality or gender that was available to her. It is her innovative combining of these discourses that makes her poetry worthy of further study.

This article addresses a fundamental aspect of Custance's poetry - the central role of Lord Alfred Douglas. For Custance, Douglas fulfilled the role of the inspiring beloved traditionally associated with the female figure of the muse. His important presence at the heart of her second volume Rainbows (1902) is key to 
enabling Custance's subversive constructions of gender and sexuality; in these poems, Douglas becomes a 'Fairy Prince' who embodies oscillating heteroerotic and homoerotic desires. I propose that for Custance, the construction of a male muse is a strategy for attaining a poetic identity; combating a masculine poetic tradition that designates women in the position of muse-object rather than poet-subject.

Custance composed her male muse from homoerotic and Sapphic elements derived from her key literary influences: Wilde, Swinburne, and Pater, as well as her personal connections with John Gray, Natalie Barney, and Renée Vivien. When she met Douglas in 1901, Custance discovered a man who fit this fantasy construction perfectly. His golden, effeminate beauty and connections with Wilde enticed her with their homoerotic connotations, yet he was also willing to have a relationship with her. Most crucially, he was disposed to play along with the idea of being objectified, and enjoyed occupying the feminine role of beloved. Custance and Douglas corresponded using three interchangeable, variously-gendered 'roles': the Prince, the Princess and the Page. This triangular dynamic allowed mobility between poet/muse positions, enabling Custance to depict the possibility of an androgynous muse, and to express bisexual desire. Problems occurred when their flexible roles became fixed in a heterosexual union, following their marriage in 1902. In this socially-sanctioned relationship, Douglas felt pressure to perform the 'manly' role of patriarch. This 'fixing' of her boyish, mercurial muse in the real world led Custance to once again resort to mythological boy lovers, and to attempt to construct herself as muse. However, this attempt may be considered a failure, as she ceased writing in 1911.

My focus in this article moves towards solving the 'problem' of Custance's marriage, which often confounds biographical narratives that would position her either as a confirmed Sapphist (in the mould of Barney), or as the long-suffering wife 
of a closeted homosexual. Both of these are reductive understandings of Custance and Douglas’ relationship that I hope to expand here. This article situates Custance's work in a milieu of decadence, aestheticism, Shakespearean and fairy-tale discourses, in order to demonstrate that Custance was at the centre of an important group of writers negotiating and reimagining fin de siècle and early twentieth-century constructions of gender and sexuality.

\section{The Fin de Siècle Male Muse}

Several studies have addressed the problems that Victorian women poets faced when they attempted to assert a poetic identity within a male-dominated literary tradition. One of the most fundamental obstacles is, broadly defined, the continuing designation of women as muses rather than poets. Feminist critics have detailed the ways in which the image of the muse as a passive inspirer of male genius can be traced throughout literary history as a means of keeping women from claiming the more active role of poet-subject. ${ }^{1}$ For Victorian women poets, the label of 'Tenth Muse', following Plato's accolade for Sappho (considered the first and greatest 'Poetess'), perpetuated the idea that women were poetry itself, not poets: 'They live and inspire it but they do not write it, while other people — namely, men — have the privilege to do so’' (Brown 2000: 181).

Although one of the few ways in which women were present within poetic tradition at all, the concept of the muse placed Victorian women poets in a difficult position when it came to constructing a poetic identity. Dorothy Mermin has summarised their dilemma in terms of trying to occupy two positions at once: the Damsel and the Knight (Mermin 1986). Throughout the nineteenth century the 
poetess remained 'less a person than a persona [...] a personified abstraction whose personal agency is suspended' (Prins 1999: 210). This is shown in numerous femaleauthored poems depicting Sappho’s suicidal leap: even at this moment of subjectivity the poetess is 'frozen [...] as an art object' (Reynolds 2003: 117). For fin de siècle women poets, the problem of the muse remained central: '[t]o become muses themselves, to have their lives appropriated and simplified in the interests of another's art' represented a persistent threat to female creative identity (Showalter 1993: xv-Xvi).

Several critics have identified the strategies by which women poets sought to resolve this crisis. One solution which is frequently invoked is the possibility of constructing an equivalent male muse. However, the two critics who have explored this avenue — Margaret Homans (1980) and Joanne Feit Diehl (1978) — find it ultimately dissatisfactory and fraught with its own problems. Tracing the male muse in the work of Emily Brontë, Elizabeth Barrett Browning, Christina Rossetti and Emily Dickinson, they use Bloomian theories of the 'anxiety of influence' to argue that for women poets, the muse is a powerful masculine precursor figure, as inhibiting as he is enabling. Homans concludes that when it comes to the gendered roles of poet and muse: 'there is no such thing $[\ldots]$ as a simple reversal of roles $[\ldots]$ the poet's ability to master her muse is in this case genuinely in question' (1980: 105).

However, the implications of Homans and Diehl's argument; that it is impossible for women poets to imagine an enabling male muse, risks constructing and perpetuating an inhibiting image of the 'Eternal Masculine'. Homans and Diehl focus on early to mid-nineteenth century women poets' attempts to construct a male muse, and use these as a basis to conclude that such an attempt will probably always fail. However, I argue that if we extend this historical focus to encompass the latter 
quarter of the nineteenth century, we find that the male muse becomes an increasingly prevalent, if not ubiquitous idea. Taking into account the fin de siècle allows the male muse to be re-imagined along more enabling, historically and culturally-specific lines.

The fin de siècle was a particularly ripe moment for imagining a male muse, due to the growing predominance of discourses of male homoeroticism circulating at the time (Dellamora 1990; Dowling 1996). These discourses influenced and inspired writers of both genders to reimagine masculinity. In contrast to Diehl and Homans, who focus exclusively on women writers' influence on each other, several recent critics have shown how 'male' and 'female' versions late-Victorian aestheticism can be considered productively alongside each other. For example, Ruth Vanita decries the 'persistence, indeed the constitutive nature, of gender segregation' in work on late-Victorian sexualities (1996: 9), tracing Sapphic and Marian narratives in the work of both men and women, whilst Talia Schaffer argues that 'in the lived reality of the 1890s, aesthetes and New Women were intimately connected and strongly allied' (2000: 18). In her important essay 'The Adolescent Boy: Fin de Siècle Femme Fatale?', Martha Vicinus argues that 'homosexuals of both sexes drew from similar cultural materials' to fashion an image of the beautiful boy (1994: 92, my italics). Meanwhile, Marion Thain has noted that although poets such Michael Field (Katherine Bradley and Edith Cooper) are 'usually examined in a way which situates [them] as part of a group of women poets [...] this positioning does little to recognise the primary intellectual affinities Michael Field had with the likes of Walter Pater, John Gray and Charles Ricketts’' (2007: 11).

Olive Custance is a poet whose work perfectly exemplifies this interpenetration of male and female influences. Indeed, her poetry can only be fully understood and appreciated if she is located within a genealogy of aestheticism that 
encompasses both genders. For example, her debut volume Opals (1897) opens with a poem inspired by a Sapphic fragment and contains numerous celebrations of female dancers, reminiscent of Baudelairean lesbian decadence. Liminal times of transition, such as twilight, feature frequently in Custance's poetry and are often personified as female, allowing her to covertly express lesbian desire under the guise of poetic convention; for example, in 'Fantasy': 'Dusk and the darkness, sisters twain, / Kiss through a silver veil of rain' (Opals 1897: 33). However, Custance also wrote several poems on the Hellenic themes associated with male homoeroticism. Indeed, it is surprising that she is only mentioned briefly in Vicinus' essay (as the lover of Renée Vivien) when the figure of the boy is so central to her work. Custance's oeuvre is densely populated with boy lovers; with poems such as 'Antinous' (Rainbows 50-1), 'Hyacinthus’ (58-60), ‘Hylas’ (61-2), ‘Endymion’ (65), and ‘St. Sebastian’ (71-2; all The Inn of Dreams, 1911) centring on beautiful and tragic male youths. ${ }^{2}$

Custance was fully aware of the layers of sexual signification she invoked when choosing to write about such figures. She spent her early twenties immersed in the society of male decadence, and hence was conversant with the homoerotic implications of an 'Antinous' or 'St. Sebastian'. This is reflected in her reading preferences: as a young woman, Custance eagerly absorbed the work of Pater, Swinburne and Wilde; her 1894 diary opens with an aphorism of Wilde's, praises Pater's Plato and Platonism and criticises Swinburne's Astrophel in terms reminiscent of the Paterian emphasis on youth. ${ }^{3}$ Custance's poetry was published in The Yellow Book alongside Baron Corvo (Frederick Rolfe), whose 'Stories Toto Told Me' contains a barely concealed homoerotic subtext, being narrated by an Italian peasant boy to his English master. For example, 'About the Lilies of San Luigi' 
directly follows one of Custance's poems in the October 1895 issue of The Yellow Book, and features the following description of St. Sebastian:

You see, sir, San Sebastiano was quite naked [...] You can see his picture in the Duomo whenever you choose, if you do not believe me. But he was so beautiful and muscular, and straight and strong, and his flesh so white and fine, and his hair like shining gold, that no one had ever thought of him as naked before. (Corvo 1895: 210)

It is likely that such descriptions influenced Custance, who later praised Sebastian's ‘curled bright hair' and 'lovely body lashed to the rough tree' (The Blue Bird 1905: 25).

During this early stage of her career, one man in particular became the model for Custance's future experiments in constructing a male muse. At the age of sixteen she encountered the poet (and supposed inspiration behind Dorian Gray) John Gray at a London party. Following their brief meeting, she wrote a series of poems describing his 'profound eyes, [his] heavy hair' ('Ideal' Opals 1897: 7). ${ }^{4}$ Thus, even prior to meeting her future husband Douglas, Custance was busy constructing a fantasy image of a male muse. She was aware that this image was only tangentially related to the living individual (with whom she did not even speak in person); as the poem 'A Mood’ makes clear by invoking an entirely imaginary figure:

I wonder shall I meet you in the night, In that dear house of Dreams, Sleep’s dwellingplace? 


\section{O Prince! O Lord of life! O heart's delight! \\ O Lover! never this side of the stars \\ Seen face to face! (Opals 1897: 57, my italics)}

Custance's endeavour to construct a male muse is fuelled by a fin de siècle context in which there was an increasing sense of 'the inadequacy of the feminine figure to the task of holding together the contradictory nature of the aesthetic' (Psomiades 1997: 178). As an enthusiastic disciple of the aesthetes, she would have encountered a number of discourses that represented the male as the ultimate object of beauty. In an 1894 article, Charles Kains-Jackson argued that the appreciation of male beauty represented 'The New Chivalry':

just as the flower of the early and imperfect civilisation was in what we might call the Old Chivalry, or the exaltation of the youthful feminine ideal, so the flower of the adult and perfect civilisation will be found in the New Chivalry or the exaltation of the youthful masculine ideal. (qtd. in White 1999: 155)

As this article boldly asserted, beauty was no longer exclusively the domain of women: the male youth was surpassing the maiden as the new aesthetic and erotic ideal. Custance would also have discovered this view in her beloved Pater. In The Renaissance (1873), Pater cites a letter in which Winckelman associates true aesthetic taste with a preference for male beauty: 'I have noticed that those who are observant of beauty only in women, and are moved little or not at all by the beauty of men, seldom have an impartial, vital, inborn sense of beauty in art [...] supreme beauty is rather male than female’ (Pater 1998: 123-4). 
Hence, with all of Custance's major literary influences engaging with discourses of 'Greek love' and homoerotic male beauty, it is little wonder that she imagined the muse as male. She constructs this muse by combining elements of both the Sapphic and male homoerotic. For example, Patricia Pulham has argued that in her statue poems, Custance merges the Dorian and the Paterian (associated with whiteness, purity, muscularity) with Sappho's more visceral, Ionian aesthetic, staining her sculptural bodies with sunset colours (Pulham 2007: 175). The next part of this article will attend specifically to how these various narratives of homoeroticism are built into Custance's understanding of her relationship with Douglas, particularly during the early stages of their courtship. I focus on Shakespearean discourses of performativity and role-play, before moving onto the fairy-tale discourses employed in her sequence of poems about Douglas, 'Songs of a Fairy Princess'.

\section{'I am tired of acting a woman's part': Shakespeare, Performativity and Role-} play

Custance and Douglas began to correspond in June 1901, after Custance sent an unsolicited letter of admiration. In this first letter to Douglas, she praises 'the fairy land of your Songs' and in her second letter she writes that 'you seem so like a Fairy Prince to me that I feel I am just going to fairy land to meet you'. ${ }^{5}$ In other early letters, Custance builds on these fantasy roles, describing herself as both a 'Page' and a 'Princess': 
But I am only your little page ... your little page with brown hair, and blue eyes almost the colour of that blue flower you sent me ... [...] from the little Princess Opal ... Since you call me a princess ... ${ }^{6}$

Custance's adoption of these two roles appears to be a way of arousing Douglas' (and her own) bisexual desires by playing with shifting gender dynamics. In a similar way to Barney and Vivien, Custance and Douglas understood their relationship through the courtly dynamic, but in their case the virginal Lady was replaced by the homoerotic Prince Charming. This role-play was constructed using discourses of male beauty and cross-dressing derived from Shakespeare. For example, in his 1926 Autobiography, after citing several letters containing Custance's enthusiastic praise of his beauty, Douglas self-consciously defends their content in terms of literary tradition:

this admiration of the girl for the boy is in itself beautiful and brave and right and classic, even if it does not commend itself to modern stupidity. Shakespeare's heroines, who are the model of everything that is perfect in womanhood, did not hesitate to express similar sentiments. (Douglas 1931: 209)

Douglas uses Shakespeare, a powerful canonical figure and national icon, to defend his wife's objectification of him: 'As a model of what may and may not be properly said on any subject, Shakespeare will always be good enough for me’ (1931: 209).

Custance also alludes to Shakespeare in an early letter to Douglas: 'I read Shakespeare's sonnets and wondered why people should have worried so much who they were written to ... because, you see, I know it was you .... Shakespeare must 
have met you in another world!' (undated, ca. August 1901, qtd. in Douglas 1931: 204). However, in moving from Romeo and Juliet (from which Douglas cites his examples) to Shakespeare's sonnets, Custance subtly shifts the emphasis from women admiring men, to men admiring men. Custance's surmises recall Wilde's 'The Portrait of Mr W.H' (1891) in which he addresses the mystery of whether the sonnets were inspired by a young boy actor named Willie Hughes. ${ }^{7}$ The unnamed narrator is introduced to this theory by Cyril Graham:

He felt $[\ldots]$ that the Sonnets were addressed to an individual, - to a particular young man whose personality for some reason seems to have filled the soul of Shakespeare with terrible joy and no less terrible despair. [...] Who was he whose physical beauty was such that it became the very corner-stone of Shakespeare's art; the very source of Shakespeare's inspiration; the very incarnation of Shakespeare's dreams? [...] surely none other than the boyactor for whom he created Viola and Imogen, Juliet and Rosalind, Portia and Desdemona, and Cleopatra herself. (Wilde 1979: 146-7)

The idea that a beautiful male youth could catalyse an artistic movement is also explored in Pater's Imaginary Portraits (1887). For example, in 'Denys l'Auxerrois', a young man inspires the building of medieval cathedrals, leading to Dionysian excess and martyrdom. Custance makes direct reference to Pater's story in a letter to Douglas: 'I was too sad to dream yesterday ... so I took up my Imaginary Portraits and read about Denys l'Auxerrois because he reminds me of you ... “a flaxen and flowery creature”’ (undated, ca. August 1901, qtd. in Douglas 1931: 204). Thus, in her early letters, Custance imagines Douglas as two pseudo-historical male muses: 
'Denys l'Auxerrois' and 'Willie Hughes'. Both are able to simultaneously embody the age and to transcend it, as their beauty is transformed into immortal art; Wilde writes that Hughes' 'true monument' will be 'the permanence of the drama. So it had been with others whose beauty had given a new creative impulse to their age' such as Antinous and Charmides (Wilde 1979: 164). By comparing her husband-to-be to these male homoerotic muses, Custance knowingly traces a line of descent from Wilde’s celebration of Douglas' youthful beauty to her own appreciation, dissolving the lines between heteroerotic and homoerotic desire.

Custance was clearly particularly inspired by the idea, propounded by Wilde's story, that Shakespeare had admired Hughes primarily for 'the versatility of his acting'; his mercurial ability to embody different female personas (Wilde 1979: 154). In the story, this theory is illustrated using Shakespeare's Sonnet 53:

What is your substance, whereof are you made,

That millions of strange shadows on you tend?

Since everyone hath, every one, one shade,

And you, but one, can every shadow lend. (qtd. in Wilde 1979: 154)

Custance's own poems are suffused with references to acting, role-play and masquerade, portraying such performance as a playful exploration of identity, as in her signature poem 'Opal Song':

Shy and wild ... shy and wild

To my lovers I have been.

Frank and wayward as a child, 
Strange and secret as a queen $[\ldots]$

False and true ... false and true

Is the woman's heart in me [...]

Changing I come back to you,

Never doubt my loyalty! (1911: 47)

In her diary, again with reference to the shifting colours of the opal stone, Custance recalls her fondness for childish games of make-believe:

I “acted” since I was six years old, I change from day to day and back again, like an opal (my friends call me Opal) in different lights... I must explain my “acting” — it is like telling a story — only instead of describing the people of my history — I become them — and all alone — with one friend or my maid for audience [...] Sometimes I invent a story but more often I act the lives of real people — my favourite "act" being the life of Lord Byron [...] indeed I often feel they [the words] are spoken against my will — that I am in fact possessed by these people of my imagination. ${ }^{8}$

By taking the opal as her symbol, Custance not only played up the fickle and flirtatious aspects of her personality, she also hinted at her bisexual tendencies. That Custance's favourite roles were seductive and heroic males (such as Lord Byron) also suggests the subversive possibilities of performative gender inversion, which she explored in her relationships with Barney and Douglas. In Paris, Barney and Vivien regularly performed tableau vivants dressed as Princes and Pages (Jay 1988). Indeed, 
Custance’s poem ‘The White Witch’ was inspired by Carolus Duran’s portrait of a ten-year old Barney dressed as the Happy Prince (Wickes 1977: 11).

These roles continued to play a key part in Custance and Douglas’ courtship: for example, in an early letter Custance sent Douglas a photograph of herself 'briefed out as a pretty boy' taken 'to please my little american friend Natalie $\underline{\text { Barney' }}{ }^{9}$ In response, Douglas expressed a preference for the Page over the Princess: 'I shan’t have anything to do with any horrid princesses [...] how could I after I have known the dear little Page?’ (Douglas to Custance, 2 October 1901, qtd. in Murray 2000: 126). Custance's masculine persona makes an appearance in the third poem of the 'Songs of a Fairy Princess’ sequence (Rainbows 1902: 7-15). This poem, entitled 'The Letter', describes a 'little page’ that brings news of the Prince to the Princess:

And there was one came in with her,

White-winged, a dainty messenger,

A little page from Love's own court,

And lovely news of you he brought (1902: 11)

The Page's appearance as go-between suggests the ways in which Custance's masculine persona mediated the early stages of her relationship with Douglas, by allowing mobility between masculine and feminine roles. Whilst for Barney and Vivien such role-play dramatized Sapphic desire, in Custance's case, she used this discourse to express bisexual desire for a homoerotically-inclined male.

In terms of this performative gender inversion, Custance resembles Sybil Vane, the actress with whom Wilde's Dorian Gray becomes infatuated. Dorian is attracted to Sybil for her ability to play a variety of different Shakespearean roles, 
including Rosalind: 'I have watched her wandering through the forest of Arden, disguised as a pretty boy in hose and doublet and dainty cap’ (Wilde 1998: 90). Unlike other women who are 'limited to their century', Sybil appears 'in every age and every costume' (Ibid). Furthermore, she regards Dorian 'merely as a person in a play’, giving him his fairy-tale name: 'I must call you Prince Charming' (Wilde 1998: 92). Sybil's forwardness (a result of her innocence) and her ability to admire Dorian and to construct fantasy roles for herself and him appeals to his narcissism. Comparably, in his Autobiography, Douglas cites Custance's active role in their courtship as one of the principal reasons for his attraction to her. Following the Wilde trials, his social withdrawal meant that in order to marry: 'it was necessary that there should be a girl who loved me very much [...] she would have to make the first advance, and a good many other advances after that' (Douglas 1931: 212). Douglas also emphasises his life-long preference for occupying the feminine role of the beloved, the pursued rather than the pursuer; a preference that shaped his relationship with Wilde and the early stages of his relationship with Custance: 'I did not for a moment intend to put up with less love and admiration from a girl than I had been in the habit of getting [...] from innumerable male friends' (1931: 214-5).

Custance's aristocratic pedigree, poetic career and willingness to adopt the masculine role of admirer convinced Douglas that she would make the perfect wife for him. Even her beauty was primarily valued as a feature that made her his equal; he explains that theirs was a union founded on similarity, in which the boy was 'just as beautiful as the girl' (Douglas 1931: 209). Douglas' biographer describes their relationship in the following terms: 
Both had a strongly homosexual nature so that the masculine side of Olive attracted Douglas while the feminine side of him attracted her. [...] By falling in love with a woman who looked like a boy and wanted to act like one, Douglas found himself at last able to have a love affair that was not damned by society. (Murray 2000: 126)

Murray’s description plays into theories of congenital inversion perhaps in order to avoid complicating Douglas' 'homosexuality'. For, as we have seen, Custance's 'masculinity' was more complex and consciously-performative than the above quotation suggests. Custance playfully constructed a boyish identity for herself, through costume and literary allusions to Shakespeare's cross-dressing heroines. However, Custance and Douglas’ roles found their ultimate expression via the fairy tale mode.

\section{Queering Prince Charming: Lord Alfred Douglas as Fairy Prince in 'Songs of a}

\section{Fairy Princess'}

Despite his burgeoning relationship with Custance, in October 1901, Douglas — disgraced in England due to the Wilde scandal and with his fortune dwindling set sail for America in the hope of finding a rich heiress to marry. When he returned in January 1902, having given up the failed plan, he found Custance engaged to George Montagu, an old school friend. He quickly persuaded Custance to change her mind and elope with him. They were married on 4 March 1902. They honeymooned in Paris and before the end of the year Custance gave birth to a son, Raymond. That same year, her second volume of poems, Rainbows was published by the Bodley 
Head. Custance dedicated Rainbows to her new husband with the inscription: 'To the Fairy Prince' (1902: v). This dedication is shortly followed by a sequence of poems inspired by their courtship entitled 'Songs of a Fairy Princess'. This 'fairy land' derives from Custance's early letters to Douglas. These five short lyrics represent Custance's romantic mythologizing of her courtship with Douglas and are set, like several of Custance's other poems, in a twilit, other-worldly 'fairy-land'.

In her important work on the female aesthete, Talia Schaffer classifies aesthetic and decadent works involving 'magical events, unconscious desires, and imaginary sites' as 'fantasias', arguing that this genre allowed fin de siècle women writers to work both within and outside of late-Victorian gender conventions, enabling possibilities denied by realist fiction:

When women writers adopted phantasmatic diction, they found it permitted new sorts of gender politics. Writers situated a woman's desires in the unreal space of 'dream' and 'fantasy,' thereby preventing the reader from criticizing the character according to everyday nineteenth-century sexual norms. (Schaffer 2000: 51)

The fairy tale genre offered a comparable opportunity to Hellenism for enabling covert depictions of homoerotic desire. Moreover, in contrast with Hellenism associated with the male homoeroticism of Victorian Oxbridge - European fairy tale was perhaps more suited to Custance who, like many women, had not received a classical education. Writing fairy tale poems enabled Custance to continue her deconstruction of rigid gender binaries whilst fulfilling the conservative expectations of women's writing to be decorative and geared towards children. That said, some reviewers were shrewd enough to notice the subversive character of these poems: 
'They are too real and too erotic. Admirable as some of them are, they had better been left unprinted, as a good deal that Paul Verlaine wrote' ('The Laureate, and Some Poets’, Saturday Review, November 1 1902: 553-4).

Custance is by no means the first fin de siècle writer to use the discourse of fairy tales to express dissident sexual desires. Oscar Wilde wrote fairy tales partly in order to express homoerotic longing, and dedicated The Happy Prince (1888) to a young American friend as: 'Faery-stories for one who lives in Faery-Land' (qtd. in Schmidgall 1995: 154). Douglas himself, whilst at Oxford, published a Uranian poem entitled 'Prince Charming' (1892), prefiguring the role he was to play in Custance's letters and poetic fantasies. Renée Vivien also wrote a short story entitled 'Prince Charming' (1904), in which a girl masquerades as her brother and marries a beautiful Princess, who describes her cross-dressed lover as 'the Prince Charming who is seen only in the childish pages of fairy tales' (Vivien 1993: 22). Karla Jay notes that the fairy-tale mode 'permitted an affirmation of Lesbian sexuality difficult to achieve convincingly within the confines of the realistic fiction of the day’ (Jay 1988: 98).

Elizabeth Goodenough argues that the fairy tale appealed to homoeroticallyinclined Victorian writers due to the Blakean image of the child as a 'literal-minded innocent [...and] creative visionary', connected to the redeeming Christ-child (Goodenough 1999: 336). The child, both as a potential reader and an imaginary construct representing freedom, innocence and hope, was enabling to writers like Custance, who wished to imagine new configurations of gender/sexuality without fear of adult judgment and censorship. The 'Uranian' or invert was even considered to have a special affinity with children, making him representative of 'the eternal World-Child' (Mayne 1909: 106). Therefore although Douglas' biographer derides the 'childishly simple sentiment' and 'little girl's emotions' expressed in Custance's 
poetry (Murray 2000: 149), this discourse of childish fantasy and play, rather than being puerile and retrogressive, is in fact an effective way of escaping the increasingly medicalised constructions of adult sexuality developed during the fin de siècle.

In keeping with Schaffer's delineation of the fantasia as an old-fashioned, conventionally feminine genre with hidden subversive potential, Custance's fairy tale poems in the 'Songs of a Fairy Princess' (1902: 7-15) sequence exhibit a similar dialectic between the heterosexist aspects of the fairy-tale genre, and its liberating possibilities as queer fantasy. For example, in the first poem 'The Princess at the Gate' (7-8), the Princess is depicted as imprisoned '[b]ehind her bars', wistfully waiting for the arrival of the Prince (8). This scenario echoes stories such as Rapunzel, with their images of female passivity and reliance on men. However, Custance's Princess is also described as an desirous lover with 'eager eyes' and 'sighs', who criticises her lover for being late, so that the courtly love dynamic of suppliant suitor and distant lady is subtly reversed. The poem teasingly proposes an erotic threat in the form of 'other men [who] pass lightly on their way' (7), recalling a letter from Custance which flirtatiously warns Douglas: 'don’t disdain my love Sweet ... many men and women have wanted it'. ${ }^{10}$ This impatient Princess will not wait forever.

In the second poem, 'The Coming of the Prince' (9-10), the Princess is encouraged to seduce the Prince: 'Kiss his sweet mouth, look deep into his eyes’ (9) — another reversal of gendered fairy tale tradition, in which the awakening kiss is usually administered by the male. Their love is described as thwarted, unfulfilled and misunderstood; the 'great world' beyond fairy land, symbolised as a 'sleepless dragon', resents their happiness, but they are protected by an angelic, Eros-like 
personification of Love: 'Love shall stand with shining wings / unfurled / Between you and the hatred of the world' (10). Custance's depiction of persecuted love (although a conventional plot of courtly love stories) resonates particularly with homoerotic allegories such as Douglas' own 'Two Loves' (1892) and Simeon Solomon's 'A Vision of Love Revealed in Sleep' (1871), in which 'Love' is an angelic androgyne, attacked and disavowed by other socially-sanctioned versions of love who sully its purity: 'Love, dethroned and captive, bound and wounded [...] his wings drooping, broken and torn’ (Solomon 1984: 292).

A delicate yet powerful figure, this angel is symbolic of the 'third-sex'; the superhuman, martyred Uranian theorised by Karl Heinrich Ulrichs and Edward Carpenter; the 'Woman-soul within a Man’s form dwelling, [...] Strange, twice-born, having entrance to both worlds’ (Carpenter 1985: 331). In an intriguing diary entry written in response to Pater's death, Custance imagines him leaving earth and ascending to the heavens:

the fair delicate soul groped amid aching doubt brushing the glory from its wide \& restless wings [...] perhaps only the angels guessed how sweet in the sight of their Creator were the blood stains on the tarnished gold of your garments [...] Your spirit has ascended to a fairer life, you move and minister among the Sons of Light. ${ }^{11}$

Custance's depiction of Pater as a Christ-like winged soul ascending to the realm of 'the Sons of Light' demonstrates her awareness of his outsider status, and recalls similar depictions of androgynous angels by Solomon. The 'Sons of Light' also hints 
at male inverts as a spiritually-superior race, recalling George Ives' secret 'Order of Chaeronea’ (Cook 2003).

Aligned with the androgynous figure of Love, Douglas is effeminised throughout these poems and placed in the position of muse-object. Described as 'fair', elusive and delicate, he displays the sort of beauty one expects of a fairy tale Princess: 'with great blue eyes and hair like gold' (10). The Prince's mouth is compared to a 'red rose-cup full of rain' ('III: The Letter' 12), an image that has feminine connotations of such vulvic symbols as the rose and the chalice (Vanita 1996: 60). Due to their shared beauty and femininity, the Prince and Princess are described in terms of physical similarity, as in the mirror-image 'when our lips and lashes meet' ('IV: A Song of Welcome' 13) — this image of sameness recalls Sappho's desire to 'Let fruit be crushed on fruit, let flower on flower' in Swinburne's 'Anactoria' (Swinburne 2004: 94). Such mirror-images suggest the narcissism that was associated with both male and female homoerotic desire in the late-nineteenth and earlytwentieth centuries; the Princess's desire resides in the Prince's ability to reflect her own golden beauty, blurring the boundaries between self and other. Similarly, in the fifth and final poem in the sequence 'Forget-Me-Nots', the speaker values the beloved's eyes for their reflective ability: 'They stare and dream through the singing / hours, / Under the turquoise and silver skies, / Under the fickle skies of Spring. / They see the sky like a looking-glass' (14).

Douglas' early poems, such as 'Prince Charming' (published in Poems 1896) suggest that he too blurred the boundaries between self and love-object. What is most striking about Douglas' poem, with its description of an idealised golden-haired, blue-eyed youth, is how similar it is to Custance's depictions of him. In an early letter, she had praised Douglas’ feminine features in the following terms: 
Oh how I miss you ... your sweet golden head ... your small red mouth [...] and above all your great blue eyes ... the most beautiful eyes a boy ever had, like two blue flowers under water (as I told you once) and those "curved lids fringed with lashes thick and long” (I think I wrote that poem to you!) (ca. October 1901, qtd. in Douglas 1931: 205)

The poem referred to, 'A Sleep Song' (1897: 31-2), features a beautiful, ambiguously-gendered figure that bears a resemblance to Douglas, though the poem was written before he and Custance met. As Custance notices in her letter, 'A Sleep Song' reveals the extent to which Douglas fit a fantasy image of the homoerotic muse that she had conceived primarily in her imagination. Douglas used similar literary and cultural materials to construct his own homoerotic 'Prince Charming'. As a result of this shared cultural context of homoerotic decadence and 'Greek love', Douglas' Prince uncannily resembles Custance's imaginary male muse with his 'curved lids fringed with lashes thick and long' and his 'short crisp curls [...] carved of shining gold’ ('A Sleep Song' 31).

\section{Losing Douglas as Muse}

Custance's 'Songs of a Fairy Princess' sequence celebrates the fluidity of her and Douglas fairy tale roles, presenting such role-play as a key part of their courtship. However, these roles became fixed following their marriage, making Custance's objectification of Douglas increasingly difficult to achieve. By Douglas' own admission, the decay of his and Custance's marriage was in part due to his 
increasingly masculine behaviour; his reaction to the pressures of married heterosexuality was to suppress the 'feminine' aspects of his personality in order to conform to Victorian ideas of masculinity:

how could I know or guess that the very thing she loved in me was that which I was trying to suppress or keep under: I mean the feminine part of me? As soon as I was married I deliberately tried to be more and more manly. The more manly I became the less attractive I was to Olive. (Douglas 1931: 215)

Adding to the pressures on their marriage, Douglas' conversion to Catholicism in 1911 precipitated a legal battle with Custance's father over the custody of their son Raymond. Custance initially sided with her father, leaving Douglas in 1913, but she returned to him in 1915 and they fought, unsuccessfully, for custody of their son. Compounding these tragic events, Raymond was diagnosed as schizophrenic in 1927 and spent the rest of his life in a psychiatric home. During this period in her life, Custance frequently expresses suicidal feelings: 'Why is Bosie so bitterly cruel to me ... How I wish I could die’. ${ }^{12}$

Just as Raymond became the contested property of the two dominant males in her life; in a similar way, Custance's poetry became subjected to controlling, suffocating forces that ultimately silenced her poetic voice altogether. Although she fondly began her third 1905 collection The Blue Bird with a poem entitled 'To My Husband', Douglas' efforts to perform the archetypal manly role appear to have had a stultifying effect on her creativity. No longer able to place her husband in the feminine position of beloved, several poems chart the process by which Custance lost 
Douglas as her muse. For example, whereas in an earlier poem 'Grey Eyes', she had celebrated her access to the male beloved's 'silent soul':

I love to look into your long sad eyes,

Those veiled inscrutable eyes that half reveal

Your silent soul $[\ldots]$

Lightly you laugh and jest like other men,

But seeing your troubled beauty, I surmise

How you have striven, suffered, sinned [...]

Because not all your subtle treacheries

Can hide from me the secrets in your eyes. (1902: 42)

In her next collection, a poem entitled 'Surrender' mourns her increasing failure to read the beloved's soul through his eyes:

I cannot fathom your blue eyes ... they are

Just mirrors for my beauty [...]

I cannot learn the secret of your smile ...

Nor understand the magic of your lips...

Nor find your moon-like soul that all the while

Suffers a strange eclipse!

Yet some mysterious power is in your hands

Since they can hold my song-birds by the wings! (1905: 39) 
In this poem, the speaker can no longer find the beautiful muse unlike 'other men'; her lover's eyes reflect only her own beauty, as the beloved refuses any longer to be the feminised object of the gaze. In his autobiography, Douglas describes how Custance 'was always desperately trying to recapture the 'me' that she had guessed and seen and loved, and only occasionally finding it concealed under various cloaks' (Douglas 1931: 215-6). 'Surrender’ dramatises Custance’s efforts to recover the beautiful Fairy Prince beneath the guise of stern patriarch that has eclipsed him. The loss of this muse figure, she fears, will bring an end to her poetic creativity; by refusing her gaze, he holds her 'song-birds by the wings'.

Observing that Douglas suffered from a temporary period of writer’s block following his marriage, his biographer notes that: 'his muse had not deserted him'; Douglas resumed creative activity with his sonnet series 'To Olive' (Murray 2000: 141). But whilst male-orientated literary tradition endorsed Douglas' entitlement to a muse, Custance found hers increasingly difficult to claim. In her last volume of poetry, The Inn of Dreams (1911), Custance attempts to counteract the loss of her muse by turning to the self for inspiration. For example, in the final poem of the volume, 'The Magic Mirrors', she objectifies her soul as a female dancer:

In the dim mirrors of imagination,

I watch the silent dancing of my soul ...

I watch her as she dances with my dreams ...

See how she takes innumerable disguises, And hides her beauty behind many masks (1911: 73) 
Reflecting on herself, Custance finds her image an obscure muse that refuses objectification. But whilst this fractured, elusive reflection may symbolise Custance's fear of becoming poetry rather than poet, this lack of unity also represents an opportunity for new inspiration located in her own self-construction. In this poem, and the more playful 'Opal Song’ (1911: 47), Custance celebrates her multifaceted literary persona. ${ }^{13}$ Such performative multiplicity offered Custance an alternative to the single, restrictive 'wife' role that endangered her poetic identity following her marriage.

Another strategy, through which Custance attempts to salvage her poetic identity, is her turn to the mythological boy muse, in poems such as 'Hyacinthus' (1911: 58-60). This boy-muse represents both a continuation of, and an alternative to, the poems in praise of Douglas that populated Rainbows. In this sense, in her final volume, Custance returns to the imaginary male muse which predated Douglas' arrival in her life. These poems imagine the death of the boy-muse as a triumph over time, preserving his beauty in the eternal 'gem-like' moment — hinting perhaps at a subconscious wish that her own boy-muse had perished at the point of perfection, rather than transformed with age into an autocratic patriarch: 'who shall mourn thy death — ah, not the / wise? / Better to perish in thy happiest hour [...] Than that the stealthy and relentless years / Should steal that grace that is thy only / dower' ('Hyacinthus’ 1911: 59-60).

However, despite the various strategies with which she experimented in The Inn of Dreams, this was unfortunately Custance's last published volume. Caught between her father and the litigious Douglas, her life from 1911 onwards is a narrative of conflict, depression and ill health. Even the handwriting of her letters deteriorates from a looping flourish to a chaotic scrawl. That this silence, like her 
poetry more generally, has occasioned little comment is perhaps due to Custance's gender, combined with her liminal historical status. The loss of Douglas, in whom she was so emotionally and creatively invested, combined with the stressful events of her adult life, brought an end to her poetic creativity. But the significance and importance of Custance's experiments in constructing a male muse represents fascinating, unexplored territory. Custance's is a queer muse: her love poems imagine radical new constructions of gender and sexuality by placing her androgynous husband in the traditionally feminine role of beloved. For this endeavour alone, her poems invite and deserve — further attention.

\footnotetext{
${ }^{1}$ For a broad history of the muse, including her classical origins, see DeShazer 1986: 1-44.

2 'Endymion' (14), 'Hyacinthus' (15-16), ‘St. Sebastian’ (25) were first published in The Blue Bird (1905).

${ }^{3}$ See Olive Custance, diary entries for June 3, June 24 and November 21 1894, The Berg Collection, New York Public Library.

${ }^{4}$ Other poems to Gray include 'Reminiscences' (38-9), 'Ritornello' (40-1) and 'The Silence of Love' (52; all Rainbows 1902).

${ }^{5}$ Custance to Douglas, undated letter (ca. June 1901), Add 81703, British Library.

${ }^{6}$ Custance to Douglas, undated letter (ca. June 1901), Add 81703, British Library.

${ }^{7}$ Douglas himself later published a study entitled A True History of Shakespeare's Sonnets (1933), in which he propounded this theory.

${ }^{8}$ Custance, undated diary entry, ca. 1906, The Berg Collection, New York Public Library.

${ }^{9}$ Custance to Douglas, undated letter (ca. June 1901), Add 81703, British Library.

${ }^{10}$ Custance to Douglas, undated letter (ca. October 1901), Add 81703, British Library.

${ }^{11}$ Custance, diary entry for November 8 1894, The Berg Collection, New York Public Library.

${ }^{12}$ Custance, diary entry for 10 April 1913, The Berg Collection, New York Public Library.
}

All works of Olive Custance, Lady Alfred Douglas (c)2010 - John Rubinstein and John Stratford, Literary Executors of The Estate of Lord Alfred Douglas - all rights reserved - unauthorised reproduction prohibited.

\section{Bibliography}

Anonymous, 'The Laureate, and Some Poets' [Review of Rainbows, by Olive Custance], Saturday Review of Politics, Literature, Science and Art, November 1 1902, pp.553-4.

Anonymous, 'Little Verse' [Review of The Blue Bird, by Olive Custance], , The Saturday Review, June 2 1906, pp. 694-5.

Barney, Natalie (1960), Souvenirs Indiscrets, Paris: Flammarion. 
Brown, Susan (2000), 'The Victorian Poetess', in Joseph Bristow (ed), The Cambridge Companion to Victorian Poetry, Cambridge: Cambridge University Press, pp. 180-202.

Carpenter, Edward (1985), 'O Child of Uranus’ [1902], in Towards Democracy (Complete Edition, foreword by Gilbert Beith), London: GMP, pp. 331-2.

Cook, Matt (2003), London and the Culture of Homosexuality 1885-1914, Cambridge: Cambridge University Press.

Corvo, Baron (1895), 'Stories Toto Told Me', The Yellow Book, Volume VII, October 1895, pp. 209-224.

Custance, Olive (1897), Opals, London: John Lane.

Custance, Olive (1902), Rainbows, London: John Lane.

Custance, Olive (1905), The Blue Bird, London: Marlborough Press.

Custance, Olive (1911), The Inn of Dreams, London: John Lane.

Custance, Olive, Correspondence with Lord Alfred Douglas, Add. 81703 (Eccles Bequest. Vol. LXXXV), British Library, London.

Custance, Olive, Holograph diary for 1895-1899, Berg Collection, New York Public Library.

Custance, Olive, Holograph diary for 1906-1909, Berg Collection, New York Public Library.

Custance, Olive, Holograph diary for 1913, Berg Collection, New York Public Library.

Dellamora, Richard (1990), Masculine Desire: The Sexual Politics of Victorian Aestheticism. Chapel Hill and London: University of North Carolina Press.

DeShazer, Mary K (1986), Inspiring Women: Reimagining the Muse, New York: Pergamon Press.

Diehl, Joanne Feit (1978), “"Come Slowly Eden”: An Exploration of Women Poets and Their Muse', Signs: Journal of Women in Culture and Society 3, pp. 572-587.

Douglas, Lord Alfred (1931), The Autobiography of Lord Alfred Douglas [1929], London: Martin Secker.

Dowling, Linda (1994), Hellenism and Homosexuality in Victorian Oxford. New York: Cornell University Press. 
Goodenough, Elizabeth (1999), 'Oscar Wilde, Victorian Fairy Tales, and the Meanings of Atonement', The Lion and the Unicorn, 23.3, pp. 336-354.

Homans, Margaret (1980), Women Writers and Poetic Identity: Dorothy Wordsworth, Emily Brontë, and Emily Dickinson, Princeton: Princeton University Press.

Jackson, Holbrook (2002), The Eighteen Nineties: A Review of Art and Ideas at the Close of the Nineteenth Century [1914], Franklin: Tantallon Press.

Jay, Karla (1988), The Amazon and the Page: Natalie Clifford Barney and Renée Vivien, Indiana: Indiana University Press.

Kains-Jackson, Charles (1894), 'The New Chivalry', in Chris White (ed), NineteenthCentury Writings on Homosexuality: A Sourcebook, London: Routledge, pp. 154-158.

Mayne, Xavier (1909), The Intersexes: A History of Simisexualism as a Problem in Social Life, in Chris White (ed), Nineteenth-Century Writings on Homosexuality: A Sourcebook (1999), London: Routledge, pp. 104-113.

Mermin, Dorothy (1986), 'The Damsel, the Knight, and the Victorian Woman Poet', Critical Inquiry, 13. 1, pp. 64-80.

Murray, Douglas (2000), Bosie: A Biography of Lord Alfred Douglas, London: Hodder and Stoughton.

Pater, Walter (1998), The Renaissance [1873], Oxford: Oxford University Press.

Prins, Yopie (1999), Victorian Sappho, Princeton: Princeton University Press.

Pulham, Patricia (2007), 'Tinted and Tainted Love: The Sculptural Body in Olive Custance's Poetry', The Yearbook of English Studies, 37. 1, pp. 161-176.

Psomiades, Kathy Alexis (1997), Beauty's Body: Femininity and Representation in British Aestheticism, Stanford: Stanford University Press.

Reynolds, Margaret (2003), The Sappho History, Basingstoke: Palgrave Macmillan.

Robbins, Ruth (1995), “A very curious construction': masculinity and the poetry of A. E. Housman and Oscar Wilde', in Sally Ledger and Scott McCracken (eds), Cultural Politics at the Fin de Siècle, Cambridge: Cambridge University Press, pp. 137-159.

Schaffer, Talia (2000), The Forgotten Female Aesthetes: Literary Culture in LateVictorian England, Charlottesville: University Press of Virginia.

Schmidgall, Gary (1995), The Stranger Wilde: Interpreting Oscar Wilde, New York: Penguin-Plume. 
Sewell, Brocard (1975), Olive Custance: Her Life and Work, London: EighteenNineties Society.

--- (1995), The Selected Poems of Olive Custance, London: Cecil Woolf.

Showalter, Elaine (1993), Daughters of Decadence: Women Writers of the Fin de Siècle, London: Virago.

Solomon, Simeon (1984), ‘A Vision of Love Revealed in Sleep’ [1871], in Simon Reynolds, The Vision of Simeon Solomon, Stroud: Capulta, pp. 43-65.

Souhami, Diana (2004), Wild Girls: Paris, Sappho and Art: The Love Life of Natalie Barney and Romaine Brooks, London: Orion Books.

Swinburne, Algernon Charles (2004), 'Anactoria’ [1866], in Jerome McGann and Charles L. Sligh (eds), Algernon Charles Swinburne: Major Poems and Selected Prose, New Haven: Yale University Press, pp. 93-100.

Thain, Marion (2007), Michael Field: Poetry, Aestheticism and the Fin de Siècle. Cambridge: Cambridge University Press.

Thornton, R. K. R. and Ian Small (1996), 'Introduction' to Olive Custance, Opals, 1897; with Rainbows, 1902, Poole: Woodstock.

Vanita, Ruth (1996), Sappho and the Virgin Mary: Same-Sex Love and the English Literary Imagination, New York: Columbia University Press.

Vicinus, Martha (1994), 'The Adolescent Boy: Fin de Siècle Femme Fatale?’ Journal of the History of Sexuality, 5 (1), pp. 90-114.

Vivien, Renée (1993), 'Prince Charming’ [1904], trans. from the French by Karla Jay and Yvonne M. Klein, in Margaret Reynolds (ed), The Penguin Book of Lesbian Short Stories, London: Penguin, pp.20-23.

Wickes, George (1977), The Amazon of Letters: The Life and Loves of Natalie Barney, London: W. H. Allen.

Wilde, Oscar (1979), 'The Portrait of Mr W. H.' [1891], in Isobel Murray (ed), The Complete Shorter Fiction of Oscar Wilde, Oxford: Oxford University Press, pp. 139169.

Wilde, Oscar (1998), The Picture of Dorian Gray [1890], Herfordshire: Broadview. 